\title{
The Application of Learning Model Type Jigsaw To Improve the Learning Outcomes of IPS Students In Class VII MTs Negeri 2 Rantau Prapat
}

\author{
Dema Yulianto \\ Department of Early Childhood Education, Universitas Negeri Jakarta, Indonesia \\ Email: radendema@gmail.com
}

\begin{abstract}
This study aims to : (1) To determine the level of learning outcomes of IPS students by using learning model Type Jigsaw. (2) To improve the learning outcomes of IPS students of MTs Negeri 2 Rantau Prapat that learned using the learning model Type Jigsaw (3) To determine the percentage increase in learning outcomes of IPS students after using the learning model Type Jigsaw. This research is a Classroom Action Research. The subject of this research is class VII MTs Negeri 2 Rantau Prapat Labuhanbatu city as many as 27 students. And the object of research is Through learning model Type Jigsaw in improving student social studies learning outcomes at MTs Negeri 2 Rantau Prapat. Based on the results of the initial test of the Value of student learning outcomes in classical before the applied learning model Type Jigsawa was of $18.5 \%$ with the criteria is very low. The value of learning outcomes of IPS students in the classical style after the applied learning model Type Jigsaw in the first cycle of $70,37 \%$, mean value obtained by the students have not yet reached the classical completeness that is equal to $>85 \%$.. This means an increase in learning outcomes of IPS students from before the action kesiklus I of 51,85\%, and from cycle I to cycle II by $22,22 \%$. From this study resulted in the conclusion that the learning model Type Jigsaw can improve learning outcomes of students of class VII MTs Negeri 2 Rantau Prapat.
\end{abstract}

Keywords: Learning Model Type Jigsaw and Learning Outcomes. 


\section{INTRODUCTION}

Education is a field that is very influential for improving the quality of Human Resources (HR). Education develops along with the development of Science and technology (SCIENCE and Technology). Everything related to education should be able to adjust the development of SCIENCE and technology. This happens because in the last century this man said to be superior if they are educated and mastered the technology. In the process of teaching and learning soerang teachers play an active role in educating kehiduapn the nation and the students, So a teacher must be able to carry out its functions as agent of learners who acts as a facilitator, boosters, engineers learning, and inspirer of learning for students. direct the learners to do on their own learning activities that require help from the teacher acts as a facilitator. The help is necessary for all of the learning process, so does the learning of Social Sciences (IPS). Regulation Of The Minister Of National Education No. 22 year 2006 on the Standard Unit Content of primary and Secondary Education which contains the Standard Competence and Basic Competence, Social Science (IPS) at the Secondary School level (JUNIOR high school), includes the geography, history, economics, and sociology. to achieve the learning outcomes are better in the learning process need to be selected teaching tools that can help students acquire more information, ideas, skills. Values and way of thinking and can make students participate in the learning process. One learning model that can be used by teachers to involve the liveliness of the students is the learning model Type Jigsaw. By using the learning model Type Jigsaw on is expected to be actively involves students and can streamline the learning social studies students as well as be able to solve problems related to social studies.

\section{RESEARCH METHODS}

\section{Jigsaw Learning Method}

At first this method was developed by Elliot Arronson from the University of Texas and later adapted by Slavin (in Nurhadi, 2003:65). Jigsaw method is a technique of cooperative learning in which students, not the teachers, who have a greater responsibility in implementing the learning. The purpose of this jigsaw is to develop team work, learning skills cooperative, and master the knowledge in depth, which may not be obtained if they are trying to learn all alone. method is:

The steps in learning according to slavin (in Nurhadi, 2003:65) by using the Jigsaw

a. The class is divided into teams or small groups consisting of $4-6$ people with different characteristics.

b. b. Every student that is in the "initial group" specializing in one part of a unit of learning. The students then meet with members of other groups who are assigned to work on the other part, and after the other master of this they will return to the initial group of them and inform the other members.

c. c. All students in the "initial group" has read the same and they met as well as discuss them to ensure understanding.

d. They then move to the "group of jigsaw" - where the members come from other groups who have read parts of different tasks. In these groups, they share their knowledge with other group members and learn new. 
e. After mastering this, all the students go home to the "initial group" and each member share the new knowledge they learn in the group of "jigsaw.

\section{The nature of learning outcomes}

A person is said to learn if it is assumed inside the person has happen to a process that resulted in a change in behavior. Activities and efforts to achieve change in behavior is the learning process while the change in behavior is the result of learning. The results of the study is an indicator to measure the success of students in the learning process. learning outcome is the ability which is obtained by students after learning activities, while learning itself is a process a person who seeks to obtain a behavior that is relatively sedentary as a result of learning. In line with this, Keller (in Abdurrahman, 2004:21) suggests that the: The results of the study are the actual achievements displayed by the child, while learning outcomes are influenced by the magnitude of the work done by the students. Learning outcomes are also influenced by the intelligence and mastery of the beginning of the child about to be studied. This means teachers need to set a goal to learn according to the capacity of the intelligence of the child and the achievement of the learning objectives with the use of apperception is the material that has been overrun child as a stepping stone to master the lesson material new.

Purwanto (2000:253) suggests that: "Learning outcomes are changes in behavior due to learning can be expressed as learning outcomes concerning various aspects of personality, both physical and psychological, such as changes in problem solving, skills, skills and attitudes". Learning outcomes are the activities of a person (student) compiling relationships between parts of information that have been obtained as understanding, therefore students understand and master these relationships so that that person can display understanding and mastery of the subject matter studied (Hudojo, 2005).

\section{Research Type and Design}

\section{RESULTS AND DISCUSSION}

Research this form of Classroom Action research (Classroom Action Reserch), which consists of four stages, namely : Planning, action, observation (observation) and reflection. This study has the objective to improve the learning process in the classroom so that learning will occur able to arouse the interest of students as well as students are able to apply the use of strategies that have been set. As for the implementation of PTK planned in this research study are as follows ; 


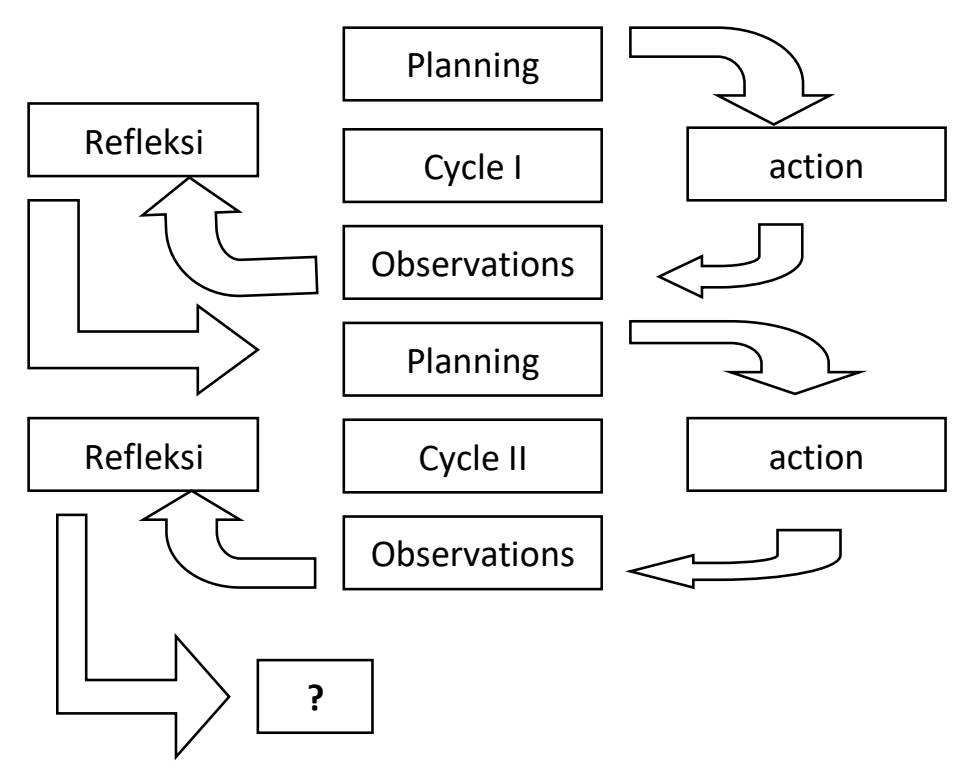

Figure 1. The Cycle Of Classroom Action Research (Arikunto, 2006:16)

\section{Research Design}

According to the type of this research is classroom action research, this study has tahanp-stage in the form of a cycle as follows:

Stage-the Stage in the cycle :

1. Planning

a. Devise a Test early

To know the understanding as well as the ability of students in solving the questions seen from the test results of the learning.

b. Designing Rencanaan pelaksanaan Pembelajaran (RPP)

So the learning that takes place is more focused so that teaching and learning activities effectively.

c. Make Observation sheet

To see how teaching and learning takes place in class.

2. The implementation of the :

a. Using Learning

b. Administration Of The Test Results Of Study I

To find out the results achieved by the students after the learning process.

3. Observation

To see whether the conditions of teaching and learning in the classroom has been implemented in accordance with the program of learning.

4. Reflection

To find out if students still lack an understanding of which is taught so that it can be used as a basis for the planning stage in cycle II

\section{Discussion}

Before Action

Based on the researchers ' observations on the course of learning before done action is supported with the instrument, namely the observation sheet and test of learning outcomes 
that are given to students, seen from the observation sheet of teacher and observation of the students, there are two things that can be analyzed, namely from the internal and external factors. Faktro the internal low interest and understanding of students in learning IPS that causes the learning outcomes of IPS students are low. External factors ie :

1. The teacher has not been able to use time efficiently and not yet able to manage the class effectively.

2. The strategy used less support in pembelajran IPS so that raises the low interest of students in learning IPS

\section{After The Action \\ Cycle I}

Based on the researchers ' observations on the course of learning after done action is supported with the instrument, namely the observation sheet and test of learning outcomes that are given to students, seen from the observation sheet of teacher and observation of the students are already showing an increase on the activity of the students that was originally not used to learn the group now began to love learning group and already getting used to apply the learning model Type Jigsaw to solve the problems.

But there are still some things that become problems that :

1. Of the factors the researchers themselves; researchers still do not effectively manage the classroom and researchers are still not able to allocate time appropriately.

2. Of the factors students; students are not fully consistent in implementing the learning model Type Jigsaw.

From the results of student learning overall in cycle I, the researcher is already enough to convey the material with a percentage calculation of the average in the classical style is $70,37 \%$ have not reached mastery in the classical and observations made on the activity of students percentage calculation of the average is from 2.76 with good category.

Based on the results of student learning is obtained before action occurs an increase of 18.5 $\%$ to $70,37 \%$ in cycle I. and it can be concluded that there is increase in the percentage of students ' ability in classical happened before the given action of the first cycle and after the action of the first cycle of 51,85\% and this result shows that the application of learning model Type Jigsaw applied by the researchers can be understood by the students. But these results are not in accordance with the specified target that mastery in the classical (> 85\%). So it can be concluded that in classical learning ability of students on the teaching is not in accordance with the set target.

\section{Cycle II}

The results of the observation on the activities of teachers or researchers and students in the second cycle shows that the implementation of the learning model Type Jigsaw to solve the problems in this research work well and effectively. Because of the problems that occur in cycle I have can be overcome with good.

After administration of the action in the second cycle by applying the learning model Type Jigsaw, obtained the level of ability of the student learning outcomes in the classical style in the first cycle of 70,37\% and in cycle II amounted stage of $92.59 \%$, can be seen an increase from cycle I to cycle II sebaesar $22,22 \%$. It can be concluded that in the classical ability level of the students already corresponds to a predetermined target $>85 \%$ so it does not need to be done cycle III.

Based on this research obtained the learning outcomes of IPS students by using learning model Type Jigsaw to solve problems can improve the learning outcomes. 


\section{CONCLUSION}

Based on the results and discussion of research, conclusions can be drawn as follows :

1. The value of student learning outcomes in classical before applying learning learning model Type Jigsaw is by $18.5 \%$ with the criteria is very low. Means the value of the learning outcomes of IPS students should be improved in the next cycle by applying the learning model Type Jigsaw.

2. The value of student learning outcomes in the classical style after learning applied learning model Type Jigsaw in the first cycle of 70,37 \% with the criteria of being mean value obtained by the students have not yet reached the kertuntasan classical amounting to $85 \%$.

3. The value of student learning outcomes in the classical style after the applied learning model Type Jigsaw in cycle II amounted stage of $92.59 \%$. mean value learning outcomes the student has attained mastery in the classical stage of $92.59 \%$ to $85 \%$.

4. Increase the value of the learning outcomes of IPS students from before action to the cycle of $51,85 \%$, and from cycle I to cycle II amounted to $22,22 \%$.

5. In cycle I, the average results of observation of the learning activities of students by from 2.76 to the medium category, and in cycle II the average results of observation of student learning activities to 3.29 with good category.

6. In cycle I, the average observation of teacher activity by 2,91 with the medium category, and in cycle II the average results of the observation of the activity of the teacher of 3,875 with the good category

\section{REFERENCES}

Abdurrahman M, Pendidikan Anak yang Berkesulitan Belajar, Jakarta, Rineka Cipta, (2003).

Arikunto, Suharsimi, Penelitian Tindakan Kelas, Jakarta, Bumi Aksara, (2006).

Dahar, Ratna willis, Teori-teori Belajar, Bandung, Erlangga, (1989).

Derija Mahulae,Upaya Meningkatkan Hasil Belajar Siswa Dalam Menyelesaikan Soal Cerita Barisan dan Deret Aritmatika Melalui Strategi Pemecahan Masalah di Kelas IX SMP 40 Medan, Medan, FMIPA UNIMED, (2008).

Gredler, Bell, Belajar dan Membelajarkan, Jakarta, CV. Rajawali, (1991).

Hudojo, Herman, Mengajar Belajar IPS, Jakarta, Depdikbud, (1998.)

Kasmah, Rusminah, Pemecahan Masalah Dalam Pembelajaran Soal Cerita Matematik, Medan, Jurnal Pelangi Badan Percetakan Universitas Negeri Medan, (2000).

Linda F. Hutabarat, Penerapan Strategi Pembelajaran Berdasarkan Masalah Pada ajar Sistem Persamaan Linear Dua Variabel di Kelas X SMAN I Dolok Masihul, Medan, (2008).

Mulyasa, E, Implementasi Kurikulum, Jakarta, Rosda Karya, (2004).

Musthafa, Adib, Bisri, Terjemah Shahih Muslim, Semarang, Asy-Syifa, (1993).

Purwanto, Ngalim, Psikologi Pendidikan, Jakarta, Grafindo Persada, (1985). 
Ruseffendi, E.T,Pengajaran IPS Modern. Bandung, Tarsito, (1980).

Sagala, Syaiful, Konsep dan Makna Pembelajaran, Jakarta, Alfabeta Bandung Terbuka, (2003)

Sanjaya, Wina, Strategi Pembelajaran Berorientasi Standar Proses Pendidikan, Jakarta, Kencana, (2008).

Sardiman, Interaksi Motivasi Belajar Mengajar, Jakarta, Grafindo, (2000).

Slameto, Belajar dan Faktor-faktor yang Mempengaruhinya, Jakarta, Rineka Citpa, (1995).

Sudirman, IPS (pelajaran IPS untuk SMP), Jakarta, Ganeca, (2007).

Sujono, Pengajaran IPS Sekolah Menengah, Jakarta, Depdikbud, (1998).

Supriyono, Agus, Coperative Learning, Yogyakarta, Pustaka Balajar, (2009).

Suryosubroto, Proses Belajar Mengajar di Sekolah, Jakarta, Rineka Cipta, (1997)

Usman, Uzer, Menjadi Guru Propesional, Bandung, Rosda Karya, (1995). 